\title{
The Effect of Charcoal on the Improvement of Grounding Resistance as a Soil Treatment in Reducing Grounding Resistance
}

\author{
Partaonan Harahap ${ }^{\varpi_{1}}$, Waleed Khalid Ahmed Al-Ani ${ }^{2,3}$ \\ 1Department of Electrical Engineering, Muhammadiyah University, Jl Kapt Mukhtar Basri Ba No 3 Glugur Darat \\ II, Medan, 20238, Indonesia, partaonanharahap@umsu.ac.id \\ ${ }^{2}$ School Of Computer and communication Engineering, Universiti Malaysia Perlis, Pauh, Khangar, Malaysia \\ waleedkh1971@gmail.com \\ ${ }^{3}$ Ministry on Industry and Minerals The State Company for Glass \& Refractories, Republic of Iraq \\ ${ }^{\otimes}$ Corresponding Author: partaonanharahap@umsu.ac.id
}

Received : February 8, 2021

Revision : February 16, 2021

Accepted : March 5, 2021

\begin{abstract}
Current technological developments are very competitive with each other, both in electric power distribution systems or electronic equipment. Disturbances that occur are usually caused by short circuits and ground disturbances, or lightning strikes. These disturbances will result in a voltage drop or increase in voltage, which results in decreased system stability, endangers people's lives, and can damage electronic equipment. Coconut Shell Charcoal has a lower resistivity value than soil and has a larger pore structure to absorb more water, and has conductive properties. The results obtained from the comparison using dry coconut shell charcoal and wet coconut shell charcoal show that measurements using wet coconut shell charcoal are better (less resistance) than using dry coconut shell charcoal. Soil resistivity measurements will be much better at the maximum depth than the usual depth $(110 \mathrm{~cm})$, better than $10 \mathrm{~cm}$.
\end{abstract}

Keywords: rod electrodes; soil disturbance; charcoal; resistivity

\section{Introduction}

Current technological developments are very competitive, whether in electric power distribution systems or electronic equipment. The disturbances that occur are usually caused by short circuits and ground disturbances, or lightning strikes. These disturbances will result in a decrease in voltage or an increase in voltage, which results in decreased system stability, endangers people's lives, and can damage electronic equipment. The ground connection protects communication and personal equipment against lightning hazards or faults in the power system and can also serve as a system. To plan a grounding system, several factors need to be considered, including soil type resistance, soil structure, environmental conditions, cost, size, and shape of the system.

Equipment grounding is the connection of parts of electrical equipment that are not normally energized by the current. Its purpose is to limit the voltage between the non-energized parts of the equipment and between the parts this part with the land comes to a price that is safe for all operating conditions, both normal conditions and when a disturbance occurs. The main purpose of grounding is to create a low impedance (low resistance) path to the earth's surface for electric waves and transient voltages. Lighting, electric currents, circuit switching and electrostatic discharge are common causes of an electrical surge or transient voltages. An effective grounding system will minimize this effect. Soil resistance is the main key determining the electrode resistance and at what depth the pins must be installed to obtain low resistance. Steel electrodes are used as a conductor for distribution channels and grounding substations.

The containment system is an important factor in the effort to secure (protection) the electric power system when a disturbance occurs due to overcurrent and overvoltage to the earth (A. Syakur., 2008). According to its function, the grounding system is divided into two parts: the neutral grounding of the power system and the grounding of the equipment. The neutral grounding of the power system aims to limit the voltages in the undisturbed phases. The equipment was earthing to prevent the occurrence of dangerous touch voltages and obtain a small or low impedance from the short circuit current to the ground (TS Hutahuruk., 1991). Based on the 2000 PUIL (General Electrical Installation Requirements), the value of the total system grounding resistance is $<5 \Omega$ (BSN., 2000). The smaller the grounding resistance value, the better the ability to flow current to the ground so that the fault current does not flow and does not damage the equipment. The value of grounding resistance is influenced by several factors: the type of soil, the size and type of electrode used, and the depth of electrode planting (Earthing Techniques).

Meanwhile, soil type resistance is influenced by soil composition, temperature, water content (moisture), and chemical content in the soil (TS Hutahuruk., 1991). One way to get a small soil resistance value and soil type resistance is soil chemical treatment (soil treatment) to add additives to the soil. Some of the additives that are often used are bentonite, gypsum, salt, and charcoal. 


\section{Materials \& Methods}

This research's test sample is coconut shell charcoal and salt $(\mathrm{NaCl})$, added to each grounding hole to reduce grounding resistance. The ratio of salt and water varies the charcoal used in this test. Charcoal has the highest percentage of carbon at $25.04 \%$, and the least amount of $\mathrm{H}$ is $4.77 \%$, based on laboratory test results. The large content of activated carbon in wood charcoal acts as an additive that can increase water absorption because it is hygroscopic. It can increase the electrical conductivity or electrical conductivity of soil (GS Pambayun at al., 2013). Salt ( $\mathrm{NaCl}$ ) This type of $\mathrm{NaCl}$ salt is used as a mixture of charcoal and water. In this study, the $\mathrm{NaCl}$ type salt will be varied with charcoal and water as described in Table 1 and Table 2. This type of $\mathrm{NaCl}$ salt has a density of $0.8-0.9$ with a melting point at a temperature of $8010 \mathrm{C}$ and has hygroscopic properties, which means it easily absorbs water. The salt solution is an electrolyte that can conduct electric current into the soil to increase the conductivity or electrical conductivity in the soil (Herman and W. Joetra., 2015).

Also, salt has properties that can bind the soil to change the composition of the soil to become denser and increase the soil's electrical conductivity.

Testing equipment

1. Digital Earth Resistance Tester 4105A Digital earth resistance tester 4105A is used to measure the measured earth resistance value with the ability to measure up to $1999 \Omega$. This tool is designed using IEC standards. Brand: Kyoritsu Power source: 9V DC battery type R6P (SUM-3) x 6

2. Digital earth tester 4105 A 2. Auxiliary electrodes consist of 2 auxiliary electrodes measuring $20 \mathrm{~cm}$ each

3. Connecting Cable The connecting Cable consists of 3 cables of different colors.

Electrode rod implantation

1. After the grounding holes are made, additives in charcoal and salt are added to several earthing holes.

2. The experiment was carried out on three PVC pipes with a length of $120 \mathrm{~cm}$ and 3 inches in diameter

3. Experiments were carried out by measuring the soil resistance that has been additives in the form of charcoal and salt are added to several grounding holes. Seen in the experimental table measuring soil resistance using a $120 \mathrm{~cm}$ electrode

Table 1. Measurement results

\begin{tabular}{ccc}
\hline $\begin{array}{c}\text { Depth } \\
(\mathrm{Cm})\end{array}$ & $\begin{array}{c}\text { Measurement results } \\
(\mathrm{Ohm})\end{array}$ & $\begin{array}{c}\text { Measurement Scale } \\
(\text { Ohm })\end{array}$ \\
\hline 10 & 1,2 & 1 \\
30 & 1,1 & 1 \\
50 & 0.6 & 1 \\
70 & 0.4 & 1 \\
90 & 0.2 & 1 \\
120 & 0.1 & 1 \\
\hline
\end{tabular}

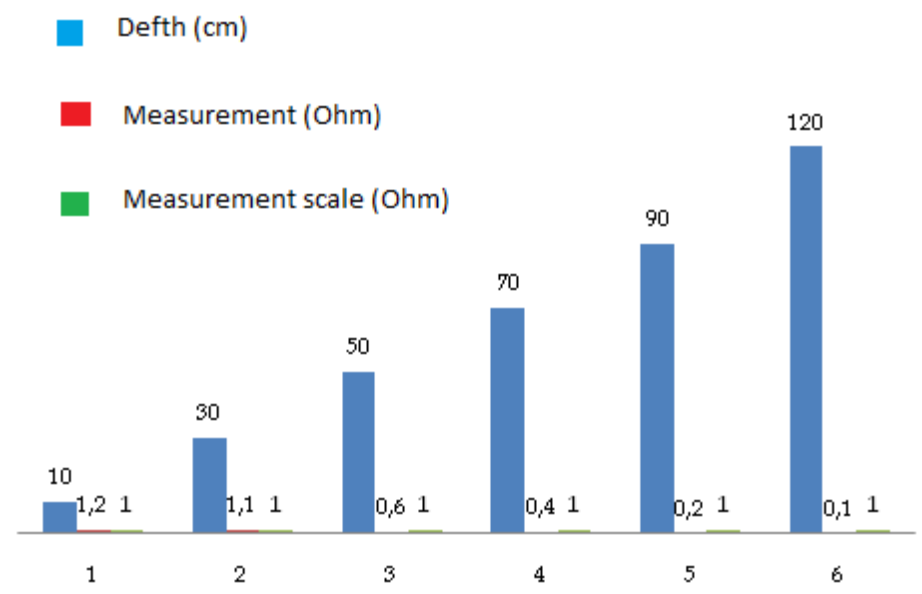

Figure 1. Graph of measurement results

\section{Results and Discussion} charcoal.

Analysis of research calculations is carried out to determine how much resistance and resistivity of coconut shell

1. Calculate RA value and value $\rho$ (tube plane ground resistance) 
Table 2.Resistance Value Calculation Results $(\rho)$

\begin{tabular}{ccc}
\hline $\begin{array}{c}\text { Depth } \\
(\mathrm{Cm})\end{array}$ & $\begin{array}{c}\text { Measurement results } \\
(\mathrm{Ohm})\end{array}$ & $\begin{array}{c}\text { The calculation results } \\
(\text { Ohm })\end{array}$ \\
\hline 10 & 1,2 & 0.16 \\
30 & 1,1 & 0.15 \\
50 & 0.6 & 0.9 \\
70 & 0.4 & 0.7 \\
90 & 0.2 & 0.5 \\
120 & 0.1 & 0.2 \\
\hline
\end{tabular}

Defth $(\mathrm{cm})$

Measurement (Ohm)

Measurement scale (Ohm)

Measurement scale (Ohm)

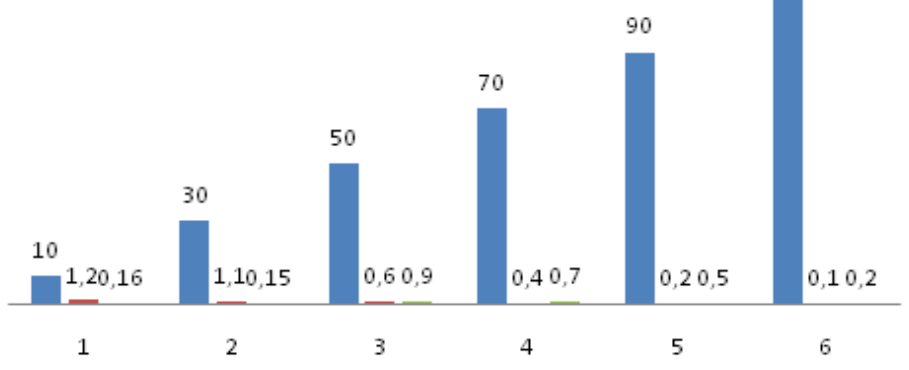

Figure 2. Graph of the Calculation of Resistance Value $(\rho)$

After doing the calculation, the results of soil resistivity are stated in table 3 of the resistivity during wet conditions.

Table 3. Value Calculation Results Resistivity (RA)

\begin{tabular}{ccc}
\hline $\begin{array}{c}\text { Depth } \\
(\mathrm{Cm})\end{array}$ & $\begin{array}{c}\text { Measurement results } \\
(\mathrm{Ohm})\end{array}$ & $\begin{array}{c}\text { The calculation results } \\
(\mathrm{Ohm})\end{array}$ \\
\hline 10 & 1,2 & 0.007 \\
30 & 1,1 & 0.002 \\
50 & 0.6 & 0.0014 \\
70 & 0.4 & 0.0010 \\
90 & 0.2 & 0.0007 \\
120 & 0.1 & 0.0004 \\
\hline
\end{tabular}

Defth $(\mathrm{cm})$

Measurement (Ohm)

Measurement scale (Ohm)

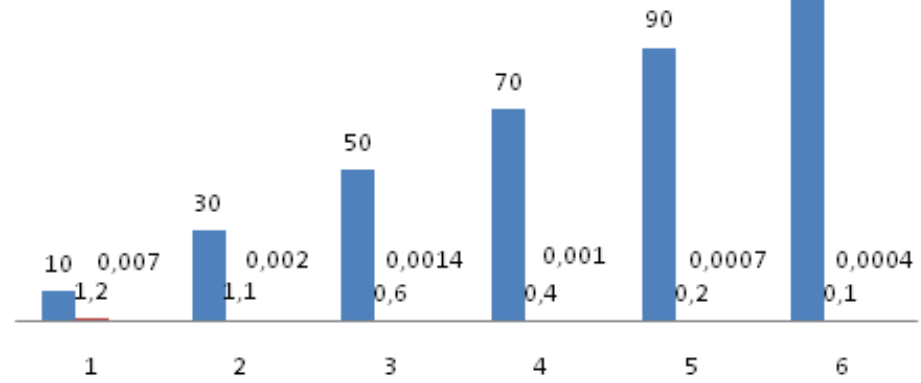

Figure 3. Graph of Value Calculation Results Resistivity (RA) 


\section{Conclusions}

After testing, it is found that the resistance value has decreased, it can be seen that the average value of the measurement results is $0.6 \Omega$ and from the calculation of resistance is $0.4 \Omega$. This is influenced by the electrode's proximity to the source of the spring in the ground so that it affects the electric current flowing through the electrode and causes the current density to decrease so that the value of grounding resistance will be smaller. Another thing is that the nature of salt as an electrolyte with very good conductivity. Besides that, the nature of salt that can bind the soil can change the soil composition to become denser to maintain the soil's water content. Soil moisture is maintained so that it can reduce the value of grounding resistance. Also, charcoal contains activated carbon, which is hygroscopic, so that it can increase the soil's electrical conductivity or electrical conductivity. The value of grounding resistance can be reduced by adding charcoal and salt additives and varying the electrode's depth. This is according to the theory where the grounding resistance value is influenced by the type of soil, the size and type of electrode used, and the depth of electrode planting.

\section{References}

A. Syakur. (2008). Comparative Analysis of Grounding Resistance Value in Soil and Septic tank, TEKNIK, vol. 29, no. 3, pp. 203-208.

TS Hutahuruk. (1991). Neutral grounding of power systems and grounding equipment, Second. Jakarta: Erlangga.

BSN. (2000). General Requirements for Electrical Installations 2000 (PUIL 2000), vol. 2000, no. PUIL.2000, p. 562.

Earthing Techniques, “Soil Resistivity Testing," pp. 1- 40.

GS Pambayun, RYE Yulianto, M. Rachimoellah, and EMM Putri. (2013) Making activated carbon from coconut shell charcoal using activators $\mathrm{ZnCl} 2$ and $\mathrm{Na} 2 \mathrm{CO} 3$ as adsorbents to reduce phenol levels in wastewater. J. Tek. POMITS, vol. 2, no. 1, pp. 116-120.

Herman and W. Joetra. (2015). The effect of table salt ( $\mathrm{NaCl})$ on the shrinkage of clay. J. Momentum, vol. 17, no. 1, pp. 13-20,

WP Widyaningsih et al. (2017). Decreasing Earthing Resistance by Using. vol. 13, no. 3, pp. 102-106.

Sudaryanto. (2016). Comparative Analysis of Earthly Resistance Value in Wet Soil, Sandy Soil and Field Soil. J. Electr. Technol. Vol. 1, No. 1, February 2016, vol. 1, no. 1.

J. Uddin and S. Sumarno. (2017). Planning an Integrated Electric Power Grounding System in Buildings. J. Electr. Electron. Eng., Vol. 1, no. 1, p. 29, DOI: 10.21070 / jeee-u.v1i1.375.

M. Mukmin, A. Kali, and B. Mukhlis. (2014). Comparison of the Value of Grounding Resistance in Coastal Reclamation Areas (CITRALAND). J. MEKTRIK, vol. 1, no. 1, pp. 29-39.

E. Yuniarti. (2016). "Gypsum as Soil Treatment in Reducing Grounding Prisoners in Fields," https://jurnal.umj.ac.id/index.php/semnastek, no. November, pp. 1-7.

M. Rajagukguk. (2012). Study of Effect of Soil Types and Grounding Depth of Driven Rod on Soil Type Resistance. Jur. Tech. Electrical, Fac. Tech. Univ. Tanjungpura.. 